\title{
Sources of Water Pollution and Selected Physicochemical Parameters of the Nyakomisaro River in Kisii County, Kenya
}

\author{
Emmy Kerich ${ }^{1, *}$, Ndege Fidelis ${ }^{2}$ \\ ${ }^{1}$ Directorate of Research and Innovation, University of Eldoret, Eldoret, Kenya \\ ${ }^{2}$ Department of Forestry and Wood Science, School of Natural Resource Management, University of Eldoret, Eldoret, Kenya
}

Email address:

emmycheptoo@gmail.com (E. Kerich),ndegefidelis@yahoo.com (N. Fidelis)

${ }^{*}$ Corresponding author

To cite this article:

Emmy Kerich, Ndege Fidelis. Sources of Water Pollution and Selected Physicochemical Parameters of the Nyakomisaro River in Kisii County, Kenya. American Journal of Biological and Environmental Statistics. Vol. 6, No. 2, 2020, pp. 17-23. doi: 10.11648/j.ajbes.20200602.11

Received: April 14, 2020; Accepted: May 6, 2020; Published: May 19, 2020

\begin{abstract}
Water is the most vital natural resource in existence as all forms of life depend on it. However, this resource is constantly polluted by human activities. Pollution of rivers is a big challenge not only in Kisii County but as a Country at large. Purposive sampling was used to identify the study area and random sampling was used to collect questionnaires. Water samples were also collected from the study site and physicochemical parameters were analysed in the laboratory. Primary data was analysed descriptively while laboratory data was analysed descriptively and statistically using t-test. Dumping of liquid and solid waste (37.2\%) and farming along the river banks $(34.9 \%)$ were some of the causes of pollution in River Nyakomisaro. The two main economic activities affecting the river are sand harvesting (30.6\%) and farming along the river banks (26.8\%). The mean value of COD, BOD, TDS, Do, $\mathrm{pH}, \mathrm{Ec}$ and Temp in Nyaguru (upstream) sampling points were $74.58 \pm 13.88 \mathrm{mg} / \mathrm{l}, 8.42 \pm 0.4 \mathrm{mg} / \mathrm{l}$, $20.25 \pm 0.5 \mathrm{~N}$. T. U, $3.75 \pm 0.21 \mathrm{mg} / 1,6.78 \pm 0.02,0.19 \pm 0.00 \mathrm{~S} / \mathrm{m}$ and $22.28 \pm 0.37^{\circ} \mathrm{C}$ respectively and the mean value of COD, BOD, TDS, Do, pH, Ec and Temp in Daraja (downstream) sampling points were $14.33 \pm 1.09(\mathrm{mg} / \mathrm{l}), 4.92 \pm 0.45(\mathrm{mg} / \mathrm{l}), 17.5 \pm 0.5 \mathrm{~N}$. T. U., $3.65 \pm 0.34 \mathrm{mg} / \mathrm{l} ., 6.84 \pm 0.02,0.18 \pm 0.00 \mathrm{~S} / \mathrm{m}$ and $22.98 \pm 0.40^{\circ} \mathrm{C}$ respectively. The concentrations of these physico-chemical parameters except Do and $\mathrm{pH}$ showed significant differences among the points $(\mathrm{P}>0.05)$. The values of all the parameters were within standards stipulated by World Health Organization except the values of Chemical Oxygen Demand. This also means that this water is not good for drinking and certain protective measures should be taken to ensure that residents depending on the source are not affected by it use. Therefore, community and town residents should be sensitized on the effects of indiscriminate disposal of waste to environment and River Nyakomisaro. Also, there should be a continuous monitoring of the water quality along the river to ensure that water is safe for consumption.
\end{abstract}

Keywords: Water, Physicochemical Parameters, Pollution and River

\section{Introduction}

Water is made up of over seventy percent of the Earth's surface and it's the most valuable natural resource in existence [1-3]. Water is crucial component of all forms of life [4-6]. Furthermore, it is a habitat [7], commodity consumed by animals and plants [8], acts as a carrier of other substances or properties such vector disease, organic and inorganic chemicals, energy and many others [9-11]. There is no other resource that affects so many areas of the economy or of human and environmental health like water [12]. However, globally 1.1 billion people lack access to safe drinking water due to water pollution [13-15].

In developing countries like Kenya, water sources for domestic use include; lakes, irrigation canals, ponds, dams, rivers, wells, borehole and rain harvested water among others, however, these sources are relentlessly polluted from both point and non-point sources due to agriculture, industrial and domestic wastes, leakages from landfills and pit latrines which contribute to organic, inorganic and aesthetic pollution of water [16-19].

[20] Recorded elevated levels of Diazinon, Fenitrothion, Cyhalothrin, Malathion, bis (2-ethylhexyl) phthalate, Dimethoate while analyzing of organic contaminants and the physico-chemical properties of borehole water of Maili-nne 
Estate and Sosiani village, Uasin Gishu County, Kenya. [21] detected the following from Athi and Kauthulini River water sources; total coliforms mean ranged between 10 and 23,830 CFU/100 mL, Escherichia coli mean range between 10 and $3480 \mathrm{CFU} / 100 \mathrm{~mL}$, Vibrio cholera, Shigella sp., Salmonella sp., Klebsiella sp., Streptococcus faecalis and Clostridium perfringens were also detected. [22] While assessing microbiological water quality of sand dams in southeastern Kenya indicated that the water from test holes and covered wells was microbiologically of better quality than the scoop holes with median TTC levels of $0 / 100 \mathrm{~mL}$ and 159/100 mL respectively. However, the median values of turbidity for both scoop holes (20-30 NTU) and covered wells (5-10 NTU) exceed the World Health Organisation (WHO) guideline values. In addition the conductivity of water from $23 \%$ of scoop holes and $26 \%$ of covered wells is above the recommended WHO limit.

A river is a natural flowing water course, usually fresh water flowing towards the ocean, sea, lake or other river. River water quality status is generally affected by many physical, chemical and biological parameters introduced by natural forces and human (anthropogenic) activities [23]. United Nation Development Program reported that approximately 1.8 million children die annually due to diarrhea which is attributed to unsafe water while in 2013, it is estimated that of 700,000 children worldwide dies as a results of diarrheal diseases resulting from drinking contaminated water [24].

River Nyakomisaro in Kisii County passes through highly populated Kisii town where many economical activities are carried out [25, 26]. Raw sewage was spotted in River Nyakomisaro, which connects to rivers Riana and Gucha that drain into Lake Victoria and residents expressed their concern over risk of contracting cholera [27]. It was vital to assess sources of water pollution to River Nyakomisaro and determine physicochemical parameters of the water. Findings of the study is hoped to help to fill the gaps by providing information on the effect of pollution of River Nyakomisaro which in return will be used in proper decision making on the effects of pollution.

\section{Methodology}

\subsection{Study Area}

Nyakomisaro sub catchment is within Kisii County. River Nyakomisaro is a tributary of River Gucha and its water serves Kisii town [28]. Kisii County is one of the 47 counties in the Republic of Kenya. It shares common borders with Nyamira County to the North East, Narok County to the South and Homabay and Migori Counties to the West. The County lies between latitude $0^{\circ} 40^{\prime} 38.4^{\prime \prime}$ South, and longitude $34^{\circ} 34^{\prime} 46^{\circ}$ 61 " East and covers an area of $1,317.5 \mathrm{~km} 2$. Kisii County exhibits bimodal rainfall pattern with average annual rainfall of $1500 \mathrm{~m}$ and temperatures that range between $21^{\circ} \mathrm{C}-30^{\circ} \mathrm{C}$. Crops grown in the country include tea, coffee, pyrethrum, maize, beans and bananas as well dairy farming. Kisii County has a population of $1,266,860$ according to [29].

\subsection{Data Collection}

\subsubsection{Secondary Data Collection}

Secondary data were collected from various documents including, administrative documents including government reports and online documents, some published and unpublished hard and soft information sources.

\subsubsection{Primary Data Collection}

Primary data was collected through the use of a structured questionnaire survey.. The study area was divided into two areas Nyanguru (upstream and Daraja (Downstream) of Nyakomisaro River. Purposive sampling was used to identify the section of Nyakomisaro River where there as pollution. The sample size was determined from the formula proposed by Yamane cited by Isreal (2009) as indicated below. Systematic random sampling procedure used to select a total of 104 sample households which were interviewed using a structured questionnaire.

Sample Size Determination

During preliminary study it was approximated that about 140 household lived along the River. Therefore sample size was determined from the formula proposed by Yamane cited by Isreal (2009), which state that:

$$
n=\frac{N}{1+N(e)^{2}}
$$

Where: $\mathrm{n}=$ sample size

$\mathrm{N}=$ target population size

$\mathrm{e}=$ level of precision (sample error)

Therefore, $\mathrm{N}=140$ households and $\mathrm{e}=5 \%$

Thus required sample size;

$$
\begin{gathered}
n=\frac{140}{1+140(0.05)^{2}} \\
\mathrm{n}=\frac{140}{1.35}
\end{gathered}
$$

$\mathrm{N}=104$

Desired sample size determined and used were 100 .

\subsection{Measurement of Physico-Chemical Parameters in the Field}

A total of 24 water samples were collected from two different sites during the wet season in 2018. Water samples were taken in a well labeled $500 \mathrm{ml}$ sampling glass container and transported to University of Eldoret for analysis. Parameters such as temperature, $\mathrm{pH}$ and dissolved oxygen were measured on site. Grab sampling was generally applied during the sampling. The samples were analyzed for following physicochemical parameters of Chemical Oxygen Demand, Biochemical Oxygen Demand, Total Dissolved Solids, Dissolved Oxygen, pH, Electrical Conductivity and Temperature by using standard methods stipulated by [30].

\subsection{Data Analysis}

Each set of questionnaires response from the farmers were 
coded and keyed in the statistical package of social scientist (SPSS version 20) to analyze data. Data was analysed descriptively and presented in tables and figures. The physicochemical parameters were analysed descriptively using SPSS version 20 and significant differences in the physicochemical parameters among sampling points was analysed with t-test.

\section{Results}

\subsection{Socio-economic Characteristics of Households}

The general information about socio-economic characteristics of household heads such as gender, age and occupation are presented in Tables 1,2 and 3 respectively.

Table 1. Sex of household head.

\begin{tabular}{lll}
\hline Gender & Frequency & Percentage \\
\hline Female & 68 & 68 \\
Male & 32 & 32 \\
Total & 72 & 100 \\
\hline
\end{tabular}

Slightly more than two thirds $(68.0 \%)$ of the interviewed household were female compared to close to a third (32.0\%) who were male.

Table 2. The age of the respondents.

\begin{tabular}{lll}
\hline Age (Years) & Frequency & Percent \\
\hline $15-24$ & 20 & 20 \\
$25-35$ & 53 & 53 \\
$36-50$ & 17 & 17 \\
51 and above & 10 & 10 \\
Total & 100 & 100 \\
\hline
\end{tabular}

Among household heads interviewed, 20\%, 53\%, 17\% and $10 \%$ fall between $15-24,25-35,36-50$ and 51 and above years' age bracket. The study shows that majority of the respondent's falls between 25-35 years' age bracket and this is the active group of the society.

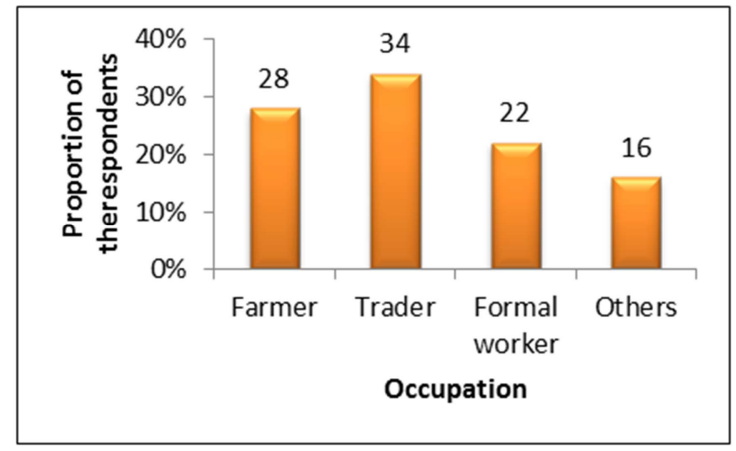

Figure 1. Proportion of occupation of the respondent.

Results showed that most of the respondents are traders $(34 \%)$ and farmers $(28 \%)$. Some of them are formal workers $(22 \%)$ and others $(16 \%)$ have different type of occupation. From the results it's apparent that most of the respondents living along River Nyakomisaro were traders and farmers.

\subsection{River Nyakomisaro Possible Causes of Pollution}

The study tried to establish the possible causes of pollution to River Nyakomisaro and results are presented in tables 3, 4, $5,6,7$ and figure 2 .

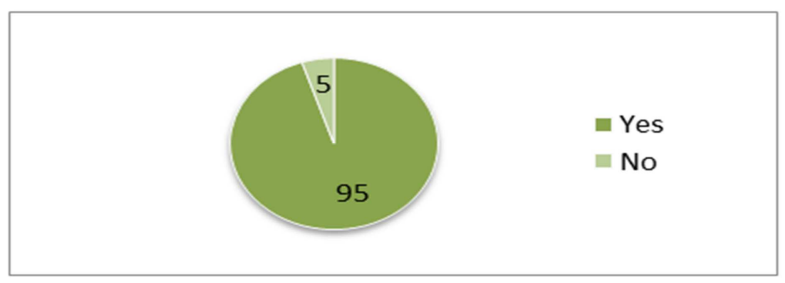

Figure 2. Possibility of pollution of River Nyakomisaro.

When the respondents were asked if River Nyakomisaro is polluted, majority of the respondents $(95 \%)$ believed that there is pollution only (5\%) of them didn't agree that there is any kind of pollution in River Nyakomisaro.

Table 3. Possible causes of pollution of River Nyakomisaro.

\begin{tabular}{lll}
\hline & Frequency & Percent \\
\hline Dumping of solid and liquid waste to the River & 96 & 37.2 \\
Cultivation along the River & 90 & 34.9 \\
Occurrence of floods & 36 & 14.0 \\
Soil erosion carrying waste into the River & 26 & 10.1 \\
Drought & 7 & 2.7 \\
No response & 3 & 1.1 \\
Total & 258 & 100 \\
\hline
\end{tabular}

Majority of the respondents $(37.2 \%)$ believed that one of the possible causes of River Nyakomisaro pollution is dumping of both liquid and solid waste to the River. Farming along the river $(34.9 \%)$ was also a major cause of river contamination among others.

Table 4. Distance from the buffer zone.

\begin{tabular}{lll}
\hline & Frequency & Percent \\
\hline $0-30 \mathrm{~m}$ & 28 & 28 \\
$30-60 \mathrm{~m}$ & 46 & 46 \\
$60-150 \mathrm{~m}$ & 16 & 16 \\
150 and above & 10 & 10 \\
Total & 100 & 100 \\
\hline
\end{tabular}

Among household heads interviewed, 28\%, 46\%, 16\% and $10 \%$ fall between $0-30 \mathrm{~m}, 30-60 \mathrm{~m}, 60-150 \mathrm{~m}$ and 150 and above meters. The study shows that majority of the respondent's live 30-60 $\mathrm{m}$ far from the river.

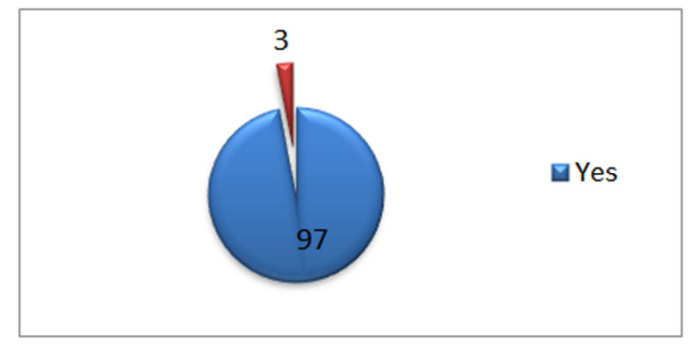

Figure 3. Possible of economic activities causing pollution of River Nyakomisaro. 
When the respondents were further asked to suggest possible economic activities causing pollution of river Nyakomisaro sources of pollution, majority of the respondents (97\%) believed that there are economic activities causing pollution, only $(3 \%)$ of them didn't agree that there are economic activities causing any kind of pollution in River Nyakomisaro.

Table 5. Possible economic activities that could lead to pollution of River Nyakomisaro.

\begin{tabular}{lll}
\hline & Frequency & Percent \\
\hline Deforestation & 59 & 19.0 \\
Mining-Sand Harvesting & 94 & 30.3 \\
Farming Along The River & 83 & 26.8 \\
Building Along The River & 51 & 16.5 \\
Oil Spillage From car/Motor Cycle Wash & 23 & 7.4 \\
Total & 310 & 100. \\
\hline
\end{tabular}

The two main economic activities affecting River Nyakomisaro are sand harvesting (30.6\%) and farming along the river banks $(26.8 \%)$ while few reported oil spillage from car and motor cycle wash $(7.4 \%)$.

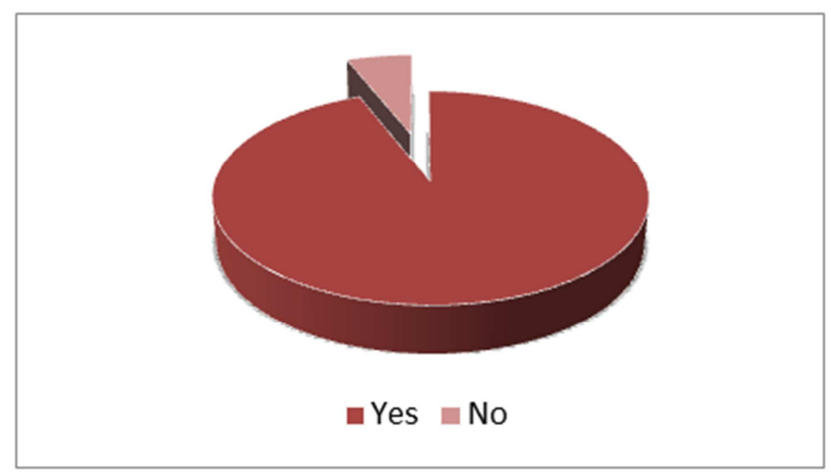

Figure 4. Environmental factors that could contribute to pollution of River Nyakomisaro.

When the respondents were asked if there are environmental factors that could contribute to pollution in River Nyakomisaro, majority of the respondents (95\%) believed that there are environmental factors that contribute to pollution only $(5 \%)$ of them didn't agree that there are any kinds of environmental factors that contribute to pollution in River Nyakomisaro.

Table 6. Current mitigation measeures taken to reduce pollution of River Nyakomisaro.

\begin{tabular}{lll}
\hline & Frequency & Percent \\
\hline Yes & 60 & 16.2 \\
No & 40 & 10.8 \\
Total & 100 & 27.0 \\
\hline
\end{tabular}

When the respondents were asked if there is any current mitigation measures taken to reduce pollution in River Nyakomisaro, majority of the respondents (16.2\%) believed that there is mitigation measures to reduce pollution, (10.8\%) of them didn't agree that there is any kind of mitigation measures taken to reduce pollution in River Nyakomisaro.
Table 7. Mitigation measures taken to reduce pollution of River Nyakomisaro.

\begin{tabular}{lll}
\hline & Frequency & Percent \\
\hline $\begin{array}{l}\text { Creating awareness on the importance of clean } \\
\text { water }\end{array}$ & 78 & 25.2 \\
$\begin{array}{l}\text { Implementation of policies to clean environment } \\
\begin{array}{l}\text { Enacting of laws that protect cutting down of } \\
\text { trees }\end{array}\end{array}$ & 85 & 27.4 \\
$\begin{array}{l}\text { Advocating for regular cleaning of River } \\
\text { Nyakomisaro }\end{array}$ & 41 & 18.1 \\
$\begin{array}{l}\text { Relocating of people who build along the River } \\
\text { Educating people on the effects of cultivating }\end{array}$ & 18 & 13.2 \\
along the River & 32 & 5.8 \\
\hline
\end{tabular}

Results indicate that measures that should be taken to protect River Nyakomisaro are implementation of policies to clean environment $(25.2 \%)$ and creating of awareness on importance of clean water $(27.4 \%)$ had the highest percentages while a relocating people who build along the River had the lowest percentage of $5.5 \%$.

\subsection{The Physicochemical Parameters of River Nyakomisaro}

The study also focused on determining the physicochemical parameters of River Nyakomisaro. Results are presented below.

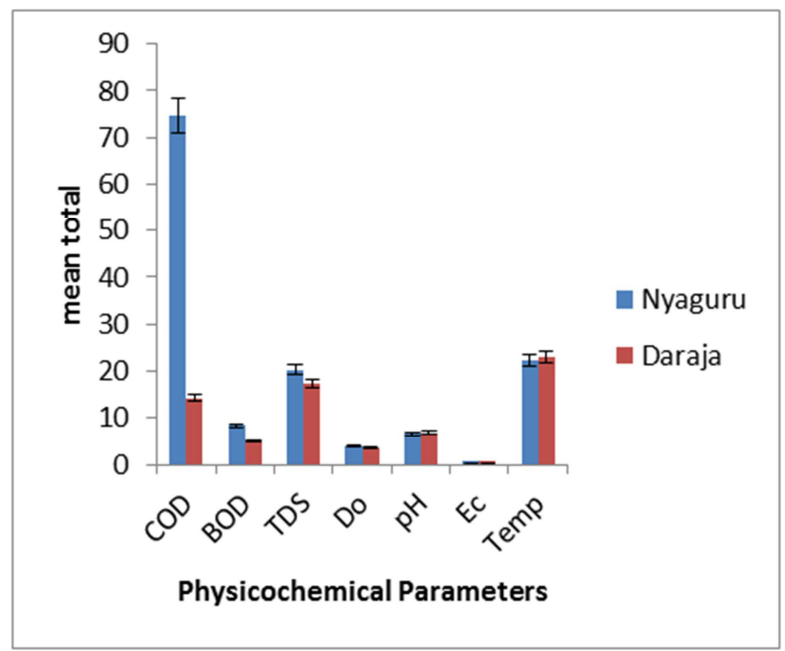

Figure 5. The mean values of physicochemical parameters of Nyanguru (upstream and Daraja (Downstream) of Nyakomisaro spring.

The mean value of COD, BOD, TDS, Do, pH, Ec and Temp in Nyaguru (upstream) sampling points were $74.58 \pm 13.88$ $\mathrm{mg} / 1,8.42 \pm 0.4 \mathrm{mg} / 1,20.25 \pm 0.5 \mathrm{~N}$. T. U., $3.75 \pm 0.21 \mathrm{mg} / 1$, $6.78 \pm 0.02,0.19 \pm 0.00 \mathrm{~S} / \mathrm{m}$ and $22.28 \pm 0.37^{\circ} \mathrm{C}$ respectively and the mean value of COD, BOD, TDS, Do, pH, Ec and Temp in Daraja (downstream) sampling points were $14.33 \pm 1.09 \mathrm{mg} / \mathrm{l}$, $4.92 \pm 0.45 \mathrm{mg} / \mathrm{l}, 17.5 \pm 0.5 \mathrm{~N}$. T. U $3.65 \pm 0.34 \mathrm{mg} / 1,6.84 \pm 0.02$ $\mathrm{mg} / \mathrm{l}, 0.18 \pm 0.00$ and $22.98 \pm 0.40^{\circ} \mathrm{C}$ respectively.

The study also determine whether there existed significant differences in the physicochemical parameters between Nyaguru (upstream) and Daraja (Downstream) of Nyakomisoro spring. Using t-test, results indicated that there was a significant difference in temperature $(\mathrm{t}=-3.075 ; \mathrm{df}=11$, $p=0.011)$, COD $(\mathrm{t}=4.570 ; \mathrm{df}=11, p=0.001)$ BOD $(\mathrm{t}=8.042$; $\mathrm{df}=11, p=0.000)$, TDS $(\mathrm{t}=3.065 ; \mathrm{df}=11, p=0.011)$ and $\mathrm{Ec}$ 
$(\mathrm{t}=4.874 ; \mathrm{df}=11, p=0.000)$. However, there no significant difference in Do $(\mathrm{t}=0.480 ; \mathrm{df}=11, p=0.640)$, and $\mathrm{pH}(\mathrm{t}=-1.981$; $\mathrm{df}=11, p=0.073)$.

\section{Discussions}

\subsection{Anthropogenic Activities Around River Nyakomisaro}

Nyakomisaro sub catchment is within Kisii County. Kisii town is located south-western Kenya, is the main urban and commercial center. River Nyakomisaro is a tributary of River Gucha and its water serves Kisii town [28]. The major causes of pollution to River Nyakomisaro reported by respondents were; dumping of both liquid (connecting of untreated sewerage channels to the river) and solid waste to the River (37.2\%). Farming along the river $(34.9 \%)$ was also a major cause of river contamination among. [27] Reported raw sewage that was spotted in River Nyakomisaro, which connects to rivers Riana and Gucha that drain into Lake Victoria and residents expressed their concern over risk of contracting cholera. A study done by [31] on water pollution identified dumping of liquid and solid waste as mainly the causes of water pollution in Delhi and recommended proper solid waste disposal system and liquid waste treatment before entering in to river. Educational and awareness programs should be organized to control the pollution. The major economic activities around the river are agriculture, car/ motocycle cleaning and sand harvesting. Improper agriculture practices and deforestation lead to land degradation and alteration of physico-chemical parameters of the River. [32] and [33] reported that population growths and developmental activities along water bodies in many sub Saharan countries have been responsible for negative changes in water quality parameters. In order to protect River Nyakomisaro, respondents suggested measure such as implementation of policies to clean environment and creating of awareness on importance of clean water had the highest percentages.

\subsection{Physico-chemical Parameters}

The mean levels of temperature recorded were $22.28 \pm 0.37^{\circ} \mathrm{C}$ in Nyaguru (Downstream) and $22.98 \pm 0.40^{\circ} \mathrm{C}$ Daraja (downstream). These levels were low and it could be due to meteorological aspects such as humidity, solar radiation and rainfall. There was a significant deference in temperature between Nyaguru (upstream) and Daraja (Downstream) of Nyakomisoro spring $(\mathrm{t}=-3.075 ; \mathrm{df}=11, p=0.011)$ could due depth difference in the downstream and upstream. Shallow waters generally warm easier and quicker compared to deeper side of the River. [34] Conducted a study in the Greek lakes and reported that variations in temperature this could be due to morphometric measurements of water bodies. [35] recorded, a slightly difference in temperature between the two sampling sites in Lake Mweru-Wantipa, Zambia. A study done by [36] water quality and plant species composition of selected sites within Chemususu dam, Baringo County, Kenya recorded a significant difference in the mean temperature between upstream Rivers and the dam; and between upstream Rivers and out flowing River with $\mathrm{C} 1$ and $\mathrm{C} 3(\mathrm{P}=0.001, \mathrm{~T}=-7.889)$; $\mathrm{C} 2$ and $\mathrm{C} 3(\mathrm{P}=0.001, \mathrm{~T}=-7.613) ; \mathrm{C} 1$ and $\mathrm{C} 4(\mathrm{P}=0.002$, $\mathrm{T}=-5.665)$, and between $\mathrm{C} 2$ and $\mathrm{C} 4(\mathrm{P}=0.004, \mathrm{~T}=-5.013)$ and it was attributed to interaction of the calm water with ambient temperature due to solar radiation could also have led to the increase in temperature in the dam.

The mean levels of Chemical Oxygen Demand (COD) recorded were $74.58 \pm 13.88 \mathrm{mg} / \mathrm{l}$ in Nyaguru (Downstream) and $14.33 \pm 1.09 \mathrm{mg} / 1$ Daraja (downstream. COD levels in our study exceeded the WHO standards of $50 \mathrm{mg} / \mathrm{l}$. [37] while investigating pollutants, determining physico-chemical characteristics of the Nairobi River and remediation of some toxic heavy metals using Fish Bones' across the sampling sites recorded COD with a mean of $260.6 \pm 248.8 \mathrm{mg} / \mathrm{L}$. There was a significant difference in COD $(\mathrm{t}=4.570 ; \mathrm{df}=11, p=0.001)$ between Nyaguru (upstream) and Daraja (Downstream) of Nyakomisoro spring. There was a general decrease of COD values downstream indicating that amount of organic matter was decreasing.

Biochemical Oxygen demand (BOD) is the quantity of dissolved oxygen needed by aerobic biological organisms in a body of water to break down organic material present in a given water sample at certain temperature over a specific time period [37, 38]. BOD mean levels were $8.42 \pm 0.4 \mathrm{mg} / 1$ in Nyaguru (Downstream) and $4.92 \pm 0.45 \mathrm{mgl}$ Daraja (downstream). The level did not exceed the KEBs standard of $30 \mathrm{mg} / \mathrm{L}$ indicating that the water had enough oxygen. This level BOD varied significantly along sampling sites $(p=0.002$, ANOVA) and ranged from 16.4 to $325.5 \mathrm{mg} / \mathrm{l}$ according to the study done by [38]. There was a significant difference in BOD $(\mathrm{t}=8.042 ; \mathrm{df}=11, p=0.001)$ between Nyaguru (upstream) and Daraja (Downstream) of Nyakomisoro spring. There was a general decrease of COD values downstream indicating that amount of organic matter was decreasing

The mean levels of Total Dissolved Solids (TDS) were $20.25 \pm 0.5 \mathrm{mg} / \mathrm{l}$ in Nyaguru (Downstream) and 3.65 $\pm 0.34 \mathrm{mgl}$ Daraja (downstream). Total Dissolved Solids (TDS) recorded significant differences $(\mathrm{t}=3.068 ; \mathrm{df}=11, p=0.001)$ between the two sampling sites. [38] Recorded a concentration which ranged from $5.6-68 \mathrm{mg} / \mathrm{l}$, values which were greatly below desirable concentration of $500 \mathrm{mg} / \mathrm{l}$ in River Kibisi, Kenya which concur with our study.

Dissolved oxygen levels measured were $3.75 \pm 0.21 \mathrm{mg} / 1$ in Nyaguru (Downstream) and 6.84 $\pm 0.02 \mathrm{mgl}$ Daraja (downstream). Using paired sample t-test, shows there was no significant difference in dissolved oxygen between sites Nyaguru and Daraja $(\mathrm{P}=0.064, \mathrm{df}=11 \mathrm{~T}=0.480)$. Low levels of DO in River Nyakomisaro were recorded during our study. This could be attributed to increase flow rate which increases turbulence causing aeration. In addition, the low dissolved oxygen may be as a result of decomposition of submerged vegetation which was not deforested during construction of the river. [36] Recorded in $\mathrm{C} 1$ the levels in $\mathrm{mg} / \mathrm{l}$ ranged from 5.3 to $7.34 ; 5.7$ to 6.4 in $\mathrm{C} 2 ; 1.7$ to 6.46 in $\mathrm{C} 3$ and 2.2 to 6.9 in $\mathrm{C} 4$. Using paired t-test, there was significant difference in dissolved oxygen between sites $\mathrm{C} 3$ and $\mathrm{C} 4 \quad(\mathrm{P}=0.001$, $\mathrm{T}=-6.944)$. Low levels of DO in Chemususu dam were 
recorded during the entire study period. This could be attributed to reduced flow rate which reduces turbulence causing aeration. In addition, the low dissolved oxygen may be as a result of decomposition of submerged vegetation which was not deforested during construction of the dam. [35] recorded the lowest and highest dissolved oxygen concentration was $1.2 \mathrm{mg} / 1$ and $12.1 \mathrm{mg} / \mathrm{l}$ measured from the National park and settlement side of the lake respectively. The oxygen concentrations on the settlement side were significantly higher than the National park side $(\mathrm{t}=-3.66$; $p=0.001$ ). Significant differences in dissolved oxygen between the study sites might have been due to a number of biotic and abiotic factors in the Lake. The dissolved oxygen levels recorded in the present study (Table 2) were within limits of natural background level of 5.0 to $7.0 \mathrm{mg} / \mathrm{l}$ that supports aquatic life.

The mean levels of $\mathrm{pH}$ were $6.78 \pm 0.02$ units in Nyaguru (Downstream) and 6.84 \pm 0.02 units Daraja (downstream). The $\mathrm{pH}$ values were within the normal range in the study area $\mathrm{pH}$ levels within the river may be due to deposition of organic matter into water due to surface runoff from forest and farmlands as well as the submerged vegetation during infilling of the dam. The partial decomposition by bacteria and fungi of this organic matter produce various organic acids that are capable of lowering the $\mathrm{pH}$. Therefore our study $\mathrm{pH}$ value was within the acceptable limit of WHO (6.0-8.5). A study of [36, 38] had acceptable limit of the $\mathrm{pH}$ in their study sites.

\section{Conclusion and Recommendation}

The values of physic-chemical parameters of temperature, Chemical oxygen Demand, Biochemical Oxygen demand (BOD), Total Dissolved Solids (TDS), Dissolved oxygen of the water quality in the River Nyakomisaro in Kisii County, Kenya were found to be within the recommended limits of WHO and KEBS standards except COD. This means that this water is not good for drinking and certain protective measures should be taken to ensure that residents depending on the source are not affected by it use. Therefore, community and town residents should be sensitized on the effects of indiscriminate disposal of waste to environment and River Nyakomisaro. Also, there should be a continuous monitoring of the water quality along the river to ensure that water is safe for consumption.

\section{References}

[1] Kuutondokwa SM: Assessment of the Impacts of Pollution on Water Quality in the Calueque-Oshakati Canal in North-Central Namibia. University of Zimbabwe, 2008.

[2] Akali N, Nyongesa N, Neyole E, Miima J: Effluent discharge by mumias sugar company in Kenya: an empirical investigation of the pollution of river Nzoia. Sacha journal of environmental studies 2011, 1: 1-30.

[3] Raji M, Ibrahim Y: Prevalence of waterborne infections in Northwest Nigeria: A retrospective study. Journal of Public
Health and Epidemiology 2011, 3: 382-385.

[4] Da Silva JF, Williams RJP: The biological chemistry of the elements: the inorganic chemistry of life. Oxford University Press; 2001.

[5] Westall F, Brack A: The importance of water for life. Space Science Reviews 2018, 214: 50.

[6] Chaplin MF: Water: its importance to life. Biochemistry and Molecular Biology Education 2001, 29: 54-59.

[7] Rousseau DP, Lesage E, Story A, Vanrolleghem PA, De Pauw N: Constructed wetlands for water reclamation. Desalination 2008, 218: 181-189.

[8] Molden D, Oweis T, Steduto P, Bindraban P, Hanjra MA, Kijne $\mathrm{J}$ : Improving agricultural water productivity: Between optimism and caution. Agricultural Water Management 2010, 97: 528-535.

[9] Coppellotti O, Fabris C, Soncin M, Magaraggia M, Camerin M, Jori G, Guidolin L: Porphyrin photosensitised processes in the prevention and treatment of water-and vector-borne diseases. Current medicinal chemistry 2012, 19: 808-819.

[10] Mariita NO: Application of precision gravity measurement to reservoir monitoring of Olkaria geothermal field, Kenya. In Proceedings World Geothermal Congress. 2000: p2719-2724.

[11] Chouhan S, Flora S: Arsenic and fluoride: two major ground water pollutants. 2010.

[12] Tavera R, Castillo S: An eutrophication-induced shift in the composition, frequency and abundance of the phytoplankton in Lake Catemaco, Veracruz, Mexico. Aquatic Ecosystems in Mexico: Status and Scope, Ecovision World Monograph Series Backhuys Publ, Leiden, The Netherlands 2000: 103-117.

[13] WHO U: UNFPA, The World Bank. Trends in maternal mortality: 1990 to 2010. World Health Organization, UNICEF, UNFPA, and The World Bank 2012.

[14] Onda K, LoBuglio J, Bartram J: Global access to safe water: accounting for water quality and the resulting impact on MDG progress. International journal of environmental research and public health 2012, 9: 880-894.

[15] Gleick PH: Dirty-water: estimated deaths from water-related diseases 2000-2020. Citeseer; 2002.

[16] Lukubye B, Andama M: Physico-Chemical Quality of Selected Drinking Water Sources in Mbarara Municipality, Uganda. Journal of Water resource and protection 2017, 9: 707-722.

[17] Kithiia SM: Water quality degradation trends in Kenya over the last decade. Water Quality Monitoring and Assessment 2012, 509.

[18] Peter-Varbanets M, Zurbrügg C, Swartz C, Pronk W: Decentralized systems for potable water and the potential of membrane technology. Water research 2009, 43: 245-265.

[19] Arnal J, García-Fayos B, Sancho M, Verdú G, Lora J: Design and installation of a decentralized drinking water system based on ultrafiltration in Mozambique. Desalination 2010, 250: 613-617.

[20] Chirchir EJ: Analysis of organic contaminants and the physico-chemical properties of borehole water of maili-nne estate and sosiani village, Uasin Gishu cCounty, Kenya. Moi University, 2016. 
[21] Nzung'a SO, Pan W, Shen T, Li W, Qin X, Wang C, Zhang L, Yu L: Comparative study of carbonic anhydrase activity in waters among different geological eco-environments of Yangtze River basin and its ecological significance. Journal of Environmental Sciences 2018, 66: 173-181.

[22] Quinn R, Avis O, Decker M, Parker A, Cairncross S: An assessment of the microbiological water quality of sand dams in Southeastern Kenya. Water 2018, 10: 708.

[23] Bonzemo S: Assessment of Water quality status of River Kibisi, Kenya using the Ephemeroptera, Plecoptera and Trichoptera (EPT) Index. Master's Thesis. Kenyatta University, Kenya, 2013.

[24] Scharf RJ, DeBoer MD, Guerrant RL: Recent advances in understanding the long-term sequelae of childhood infectious diarrhea. Current infectious disease reports 2014, 16: 408.

[25] Shook A: A Study of 24-Hour High Flow Events in Small Scale New York State Watersheds. 2009.

[26] Olang LO, Kundu PM: Land degradation of the Mau forest complex in Eastern Africa: a review for management and restoration planning. Environmental Monitoring 2011: 245-262.

[27] Daily Nation: Outraged residents demand solution for filthy, stinking Kisii Town. In.; 2018: 549-558.

[28] UN-Habitat: Lake Victoria Water and Sanitation Initiative; Fast Track Capacity Building Programme for Utilities.. 2008.

[29] Statistics KNBo: 2019 Kenya Population and Housing Census. vol. Volume I: Population by County and Sub-County. pp. 20; 2019: 20.

[30] Apha A: Standard methods for the examination of water and wastewater. American Public Health Association. Inc, Washington, DC 1998.
[31] Ahmed S, Ismail S: Water pollution and its sources, effects \& management: a Case Study of Delhi. Shahid Ahmed and Saba Ismail (2018)'Water Pollution and its Sources, Effects \& Management: A Case Study of Delhi', International Journal of Current Advanced Research 2018, 7: 10436-10442.

[32] Yorke C, Margai FM: Monitoring land use change in the Densu River basin, Ghana using GIS and remote sensing methods. African Geographical Review 2007, 26: 87-110.

[33] Ayivor J, Gordon C: Impact of land use on river systems in Ghana. West African Journal of Applied Ecology 2012, 20: 83-95.

[34] Stefanidis K, Papastergiadou E: Relationships between lake morphometry, water quality, and aquatic macrophytes, in greek lakes. Fresenius Environmental Bulletin 2012, 21: 3018-3026.

[35] Anamunda A: Relationships between abundance of zooplankton and physico-chemical parameters in lake Mweru-Wantipa, Zambia. Sokoine University of Agriculture, 2015.

[36] Manohar S, Kitur E, Kibet F: Water Quality and Plant Species Composition of Selected Sites within Chemususudam, Baringo County, Kenya. J Environ Anal Toxicol 2016, 6: 2161-0525.1000390.

[37] Masese FA: Investigation of pollutants, determination of physical chemical characteristics of the Nairobi River and remediation of some toxic heavy metals using fish bones. MSc Theses, Department of Chemistry, University of Nairobi 2010: 27-28.

[38] Walakira P, Okot-Okumu J: Impact of industrial effluents on water quality of streams in Nakawa-Ntinda, Uganda. Journal of Applied Sciences and Environmental Management 2011, 15. 